\title{
$\mathrm{R}_{\text {ESENSI }}$ BUKU
}

\section{Farmer Led Extension: Concepts and Practices}

$\begin{array}{ll}\text { Editor } & : \text { Vanessa Scarborough, Scott Killough } \\ & \text { Debra A Johnson dan John Farrington } \\ \text { Penerbit } & : \text { Overseas Development Institute } \\ \text { Tahun Terbit } & : 1997 \\ \text { Jumlah halaman } & : 214\end{array}$

\section{Suwignya Utama dan M. Nur Sangadji.}

\section{Pendahuluan}

Sekitar sebelas tahun lalu, Juli 1995, di Filipina lebih dari 70 orang dari berbagai negara, yang memiliki latar belakang profesi beragam, berkumpul untuk sebuah workshop bertaraf Internasional dengan tajuk Farmer Led Extension.

Lokakarya yang diselenggarakan oleh Overseas Development Institute (ODI), International Institute for Rural Reconstruction (IIRR) dan World Neighbors di Filipina, bertujuan untuk "berbagi pengalaman dalam pelaksanaan penyuluhan.“

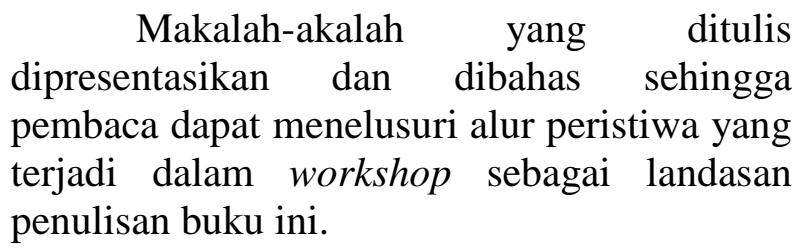

Workshop tersebut menghadirkan partisipan dengan profesi yang beragam, mulai dari petani, penyuluh pertanian, wakil pekerja masyarakat, staf NGO, wakil sektor publik, wakil donor dan akademisi.
Para peserta itu membahas lebih dari 50 makalah dan mendiskusikan berbagai aspek farmer-led extension.

Salah satu keluaran workshop tersebut adalah buku Farmer-led extension ini. Keluaran lain ialah buku/dokumentasi tentang Farmer extensionist, buku cerita tentang Farmer-led extension, 17 studi kasus, video tentang pendekatan Farmer led extension, sebuah petunjuk praktis tentang Farmer-led Extension dan sebuah manual untuk pelatihan bagaimana membentuk dan mengelola pendekatan Farmer-led extension.

Patut dicatat, kebanyakan workshop, terutama yang dilaksanakan di dalam negeri, kerap berakhir sebagai wacana, dengan menyertakan atau meninggalkan sedikit laporan dalam bentuk prosiding. Sekedar untuk pertanggungjawaban atau kelak hanya menjadi hiasan lemari semata.

Penerbitan buku ini tentu diharapkan menjadi bahan yang terbaca secara luas, sehinga gagasan yang muncul dalam workshop bisa dilaksanakan dalam skala yang lebih luas. 
Tantangan penyuluhan pertanian abad 21 ditandai oleh cepatnya perkembangan teknologi yang disertai dengan munculnya berbagai permasalahan budaya, sosial, ekonomi, politik, administratif dan dimensi diplomasi yang harus dipertimbangkan dalam penyuluhan.

Dunia pertanian diharapkan bisa menghasilkan produk guna memenuhi kebutuhan petani dan penduduk lain, terutama di areal perkotaan. Karena itu, Penyuluhan pertanian harus memfokuskan diri pada peningkatan produksi pertanian secara ekonomis dan menjaga kondisi lingkungan hidup yang baik.

Penyuluhan oleh petani ke petani atau petani sebagai agen perubahan merupakan model pendekatan penyuluhan pertanian untuk menjawab permasalahan bahwa penyuluhan yang dilakukan sektor publik lebih terkonsentrasi pada areal pertanaman yang mendapatkan irigasi.

Sementara itu, banyak petani yang berada pada areal yang tidak terjangkau irigasi masih tetap hidup dalam kemiskinan dan belum terjangkau layanan penyuluhan.

Dalam banyak pengalaman, sistem penyuluhan yang dilakukan oleh pemerintah dan didukung oleh ahli pertanian terkesan kurang mendengar petani, dalam arti kurang menjawab kebutuhan sesungguhnya dari petani. Petani berskala kecil dengan usaha pertanian campuran pada lahan kering dataran tinggi misalnya, termasuk pihak yang terabaikan.

Karena itu, perlu suatu sistem penyuluhan yang membantu petani mengorganisasikan diri untuk memberdayakan dirinya. Kelompok eksternal (outsider) hanya akan berfungsi sebagai fasilitator saja, untuk meningkatkan kepasitas petani guna menolong diri mereka sendiri (helping farmer to help them self).

Buku ini dirancang dengan format sederhana, namun cukup lengkap menyajikan berbagai proses dalam workshop itu. Buku ini terdiri dari 14 bab, ditambah kata pengantar editor, singkatan, tabel, gambar, dan daftar makalah yang ditulis sehingga memungkinkan pembaca untuk menelusuri alur peristiwa yang berlangsung dalam workshop sebagai landasan penulisan buku ini.

\section{Pengertian Farmer-led Extension.}

Penyuluhan oleh petani didefinisikan sebagai suatu proses komunikasi berbagai arah antara penyuluh dan petani yang saling berbagi dan mengembangkan pengetahuan dan keterampilan untuk memenuhi kebutuhan berusahatani dan mengembangkan kapasitas inovatif di antara para aktor.

Peranan petani sebagai pusat kegiatan pengembangan dan penyebaran teknologi serta melibatkan petani untuk melatih petani lain dalam berbagai pengetahuan dan keterampilan.

Definisi ini dikembangkan secara skematik dan lebih operasional oleh partisipan workshop dengan uraian seperti pada box dibawah ini.

\section{Kandungan Buku}

Bab 1, di bawah berisi informasi tentang workshop, mulai dari latar belakang, tujuan dan kegunaan hingga defenisi dan aktor dalam konsep Farmer led extension.

Bab 2 dan 3 memuat hasil suntingan dari keynote papers yang dipresentasikan oleh George Axinn (Michigan State University, USA) dan Chris Gorforth dan Nicola Harford (University of Reading, UK) pada workshop tersebut.

Pada Bab 2, Axinn menekankan lima tantangan yang dihadapi pertanian pada masa mendatang yaitu: pengawasan dan akuntabilitas, keberlanjutan ekologi, peran wanita dalam pertanian dan penyuluhan, partisipasi dan korupsi. Pada Bab 3, Garforth dan Hardford mengidentifikasi empat 


\begin{tabular}{|l|l|}
\hline Apa & Proses komunikasi multi arah \\
\hline Oleh Siapa & Antara dan di antara staf penyuluhan dan petani. \\
\hline Melakukan apa & $\begin{array}{l}\text { Pelibatan dalan hal berbagi sumber dan pengembangan } \\
\text { pengetahuan dan ketrampilan. }\end{array}$ \\
\hline Mengapa & $\begin{array}{l}\text { Untuk menemukan kebutukan pertanian dan mengembangkan } \\
\text { kapasitas inovatif di antara semua aktor. }\end{array}$ \\
\hline Peran Patani & $\begin{array}{l}\text { Petani memiliki kemampuan untuk mengontol keinginannya : } \\
\text { sebagai pusat dalam pengambilan keputusan, memainkan peran } \\
\text { kunci dalam pengembangan dan alih teknologi, melibatkan petani } \\
\text { dalam melatih petani dan pelatih lainnya dan dalam berbagi } \\
\text { (sharing), sumber dan transfer pengetahuan dan ketrampilan. }\end{array}$ \\
\hline
\end{tabular}

kecenderungan dalam pandangan penyuluhan, diskusi peran pemerintah dalam dunia penyuluhan dan implikasi keberlanjutannya dan mengidentifikasi tujuh isu kunci yang mendesak berdasarkan pengalaman 20 tahun sebelumnya.

Bab 4 - 7 menekankan pada bentuk asli dari penyuluhan "petani ke petani" (farmer to farmer extension). Bab 4 menguraikan tentang awal mula dan evolusi dari jaringan kerja sama dari bentuk penyuluhan petani ke petani di Amerika Latin, Indonesia, Philipina, Vietnam, Nepal dan India. Bab 5 mengandung ringkasan dari prinsip-prinsip bagaimana sebuah kerja sama dibangun dan berbagai metoda lapangan yang dikembangkan. Bab 6 menguraikan peran dari para aktor utama-penyuluh pertanian, penyuluh professional dan agen penunjang. Bab 7 menguji berbagai reaksi terhadap beberapa isu utama, masalah dan pertanyaan menyangkut "Penyuluhan petani ke petani" dalam wujud prakteknya.

Bab 8-11 menguraikan berbagai pendekatan lain yang dapat digolongkan sebagai bagian yang mendukung konsep Farmer-led extension. Bab 8 membicarakan sekolah lapangan bagi petani, suatu metoda yang dikembangkan terutama di Asia Tenggara atas kerja sama sektor publik dan NGO untuk membantu petani belajar dan menemukan solusi dari masalah yang mereka hadapi. Bab 9 menguraikan konsensus masalah atau problem solving approach dengan mambandingkan suatu proyek yang dilakukan di Nepal dan Banglades oleh sistem penyuluhan pemerintah dan sistem penyuluhan sektor publik yang lebih responsif terhadap kebutuhan lokal.

Bab 10 menguraikan sejumlah usaha yang bertujuan mengembangkan hubungan kerja sama di antara petani, NGO dan sistem penyuluhan sektor publik. Bab 11 memaparkan sejumlah studi kasus yang berkaitan dengan Farmer led extension di berbagai negara seperti Banglades, Zimbabwe, Mesir, dan India.

Bab 12 memfokuskan pada analisis dampak penerapan konsepsi Farmer-led Extension dengan melihat berbagai kelemahan dan kelebihan, dibandingkan dengan penyuluhan konvensional.

Bab 13 menguraikan usaha yang dapat dilakukan untuk meningkatkan atau menyebar luaskan konsep Farmer-led extension ini, yang aplikasinya masih terbatas.

Bab 14 menggambarkan suatu hikmah lessons learned melalui pelibatan sejak tahap awal, implementasi dan manajemen dari Farmer-led agricultural extension dan pelayanan penelitian, termasuk beberapa hal yang harus diprioritaskan untuk kegiatan selanjutnya yaitu: dokumentasi, penelitian dan analisis.

\section{Lessons learned}

Penyuluhan petani ke petani dapat bermanfaat untuk mengisi kekosongan peran pemerintah dalam penyuluhan terutama pada lokasi tertentu yang sulit dijangkau. Agar 
penyuluhan oleh petani bisa diterapkan dengan baik, perlu perubahan peran sektor publik dalam penyuluhan, perubahan pola alokasi sumberdaya dan perubahan kontrol atau pengawasan lokal terhadap sumberdaya.

Penyuluhan oleh petani, dengan demikian akan memiliki prospek yang baik dalam mempengaruhi disain dan implementasi program penyuluhan sektor publik.

Namun demikian, berbagai pendekatan tentang penyuluhan oleh petani bukanlah suatu model untuk mengtasi segala masalah, karena semuanya akan sangat tergantung pada peran-peran institusi dan kombinasi berbagai kondisi tertentu.

Meskipun buku ini dicetak pada tahun 1997, dua tahun setelah penyelenggaraan workshop yang berlangsung dua belas tahun lalu, isi buku yang mengulas pergulatan pemikiran, sharing pengalaman dan lessons learned tentang Farmer-led extension dalam workshop tersebut terasa kian relevan terutama ketika kita menyoal keterpurukan dunia penyuluhan di Indonesia saat ini.

Otonomi daerah telah berimplikasi pada lepasnya kendali penyuluhan ke daerah. Sayang, oleh banyak pemerintah daerah, penyuluhan dipandang sebagai sektor marjinal karena tak bisa menjadi mesin uang untuk PAD sehingga nasib sektor penyuluhan benar-benar terabaikan.

Tentunya buku ini tidak akan mungkin memuat semua teks lengkap dari lebih 50 makalah dalam workshop (lihat appendix 2). Tujuh belas makalah telah dipublikasi secara lengkap pada ODI's Agricultural Research and Extension Network Paper 59 (Scarborough 1996), dan tersedia di ODI. Sedangkan, makalah lain dengan teks lengkap dapat diperoleh dari IIR.

Walaupun uraian buku ini lebih banyak membicarakan masalah penyuluhan di sektor pertanian, namun sesungguhnya relevansinya bisa menjadi patokan, bahkan bila perlu dapat diduplikasi untuk sektor yang lain. Sebagai contoh dapat disebut untuk sektor pendidikan, dengan istilah Student led extension (peer education), victim led extension untuk bencana alam atau bencana sosial, sektor kesehatan, agama dan lain-lain.

Oleh karena itu, akan sangat merugi terutama bagi kita yang berkecimpung di dunia penyuluhan bila tak sempat membaca buku ini. Masalahnya kita tidak mengetahui kalau kita merugi. Maka, bergegaslah untuk membacanya dan menerapkannya agar supaya dunia penyuluhan bisa bergairah di tanah air. Atau, paling tidak, kita akan memperoleh wawasan baru bahwa penyuluhan tidak hanya bisa dilakukan oleh sektor publik. Ada dimensi dan cara pendekatan lain, yaitu dari petani ke petani.

Akhirnya, betapun sering diabaikan, karena dianggap kecil kontribusinya, kita tetap berharap dengan bergairahnya dunia penyuluhan, negeri ini bisa menemukan kembali ruh kebangkitannya. Semoga. 